\title{
Innovative Practices in College Libraries
}

In an effort to determine the extent to which college libraries were engaged in innovational practices, a questionnaire was sent to 1,193 institutions having liberal arts programs. The document sought the identities of libraries currently engaged in any of a number of selected activities thought by the compiler to be relatively recent in their introduction to library practice. Replies are tabulated and commented upon.

$\mathrm{T}$ HIS REPORT of an inquiry, sponsored by the Institute of Higher Education at Teachers College, Columbia University, was undertaken as part of a study of innovation in liberal arts colleges. Its purpose was to identify innovative developments in liberal arts college libraries. Innovation was defined to embrace a range from change to complete novelty. The information was assembled from responses to a checklist of innovative library practices. The list was assembled from recent indexes to College \& Research Libraries ${ }^{1}$ and Library Literature. ${ }^{2}$ The questionnaire was not tested. The thirty-three items on the list were grouped in several categories: administrative practices, automation, computer use, materials, physical facilities, and special library services and resources. The 1,193 institutions selected for mailing were those identified in the most recent issue of the Education $D i$ rectory as having liberal arts programs. ${ }^{3}$

\footnotetext{
${ }^{1}$ Association of College and Research Libraries of the American Library Association, "Index to College \& Research Libraries," XXVII (1966).

${ }^{2}$ Library Literature, 1933-35. Various issues for the year 1967.

${ }^{3}$ U.S. Office of Education, Education Directory, Part 3, Higher Education (Washington, D.C.: Government Printing Office, 1967).
}

Dr. Forman is Librarian of Teachers College, Columbia University.
The questionnaire, with a return envelope, was addressed to the librarian of each institution and mailed on December 20, 1967. Seven hundred and eightyone libraries, 65 per cent of those queried, had responded by March 15 , 1968. A copy of the questionnaire with a collation of the responses is attached.

In the category of administrative practices the thrust of innovative change reported was toward the adoption of $\mathrm{Li}$ brary of Congress classification-presumably a change from the Dewey Decimal Classification or other systems. Approximately 43 per cent (336) of the reporting institutions have adopted the LC classification, and 31 per cent (243) of the total have done so since 1961 . Ten per cent (79) of the institutions are now planning to do so. Whether this change has any significance at all for the process of teaching and learning in the liberal arts college is questionable. Its greatest potential lies in the economics of cataloging the books and placing them on the shelves. The problem of centralized cataloging and classification has long engaged the interest of librarians. The current trend appears to be directly linked to Part C of Title II of the Higher Education Act of 1965, by which the Federal Government accepted responsibility for the centralized cat- 
aloging of scholarly books as part of its support for higher education. ${ }^{4}$

Thirty-nine per cent of the libraries (308) report multi-media materials in their catalogs, 25 per cent (193) report special catalogs of multi-media materials, and 22 per cent (170) are using various media in their programs of instruction in library use. These include films, slides, and video-tape. Academic libraries obviously are responding to the fact that modern technology is producing the record of mankind and communications materials in new forms, and responding to faculties that are recognizing the range of individual differences in young people. But little is empirically known about the extent to which these audiovisual materials help in the teaching/learning process. ${ }^{5}$

One of the more ubiquitous innovations in the college library could probably be categorized as a tribute to the copying machine industry. Seventy-four per cent (578) of the respondent libraries were equipped with copying machines, 61 per cent (476) introduced them since 1961, and 4 per cent (32) are planning to make such equipment available. Similarly innovative is the use of the reader-printer, reported in use by some 42 per cent (330) libraries and considered in the plans of 17 per cent (134) of the others. Such equipment is having a profound influence on the role of the library as a distributor of information, but it is introducing new problems of concern with copyright law. The use of other kinds of machinery has grown less rapidly. One hundred (13 per cent) mechanized circulation systems are now installed, 11 per cent of these since 1961; but 134 (16 per cent)

\footnotetext{
4 John W. Cronin, et al., "Centralized Cataloging at the National and International Level," Library Resources and Technical Services, XI (Winter 1967), 27.

${ }^{5}$ Richard E. Chapin, "Use of Printed and Audiovisual Materials for Educational Purposes by College and University Students," in Columbia University, School of Library Service, Conference on the Use of Printed and Audiovisual Materials for Instructional Purposes, ed. by Maurice F. Tauber and Irlene $\mathbf{R}$. Stephens (New York: Columbia University, 1966), 57-71.
}

institutions are planning to introduce them. The Brooklyn College library pioneered in the use of an IBM punched card circulation system as early as February 1950. This kind of mechanization promises to expand the capabilities of loan desks to handle larger numbers of borrowers, and to improve record keeping procedures. As for other methods of technology, it is apparent that the teletypewriter and facsimile transmission are piquing the interest of librarians. An experimental network using these technologies is already in operation in New York State. Five academic libraries in Connecticut are linked in a teletype network with the Connecticut State Library. Academic institutions and the State Library in Oklahoma are involved in a similar hookup. The major use of this system is to effect interloans and provide book location service.

The computer made no significant appearance on the library scene before 1961. Computers are rarely integral to the library itself; their high cost limits their use by libraries except when they are installed for other institutional uses and therefore also are available to the library. The number of institutions which are considering the introduction of computer technology, compared to the numbers using it, suggests that this is the innovation of the future. Institutions such as Florida Atlantic have attempted to produce book catalogs; Wayne State, Michigan, Michigan State, and Florida State are producing computerized media catalogs. ${ }^{6}$ Computer use in the library is supported by the growing number of courses on computer technology in library schools, as well as the number of institutes and summer courses for professional librarians. Computer technology holds forth considerable promise for the mechanization of conventional procedures such as circulation control and serial records, and for bibliographical control and text access. Small

\footnotetext{
'William J. Quinly, "Computerized Cataloging," Audiovisual Instruction, XII (April 1967), 321.
} 
beginnings have been made to harness the computer potential to self-instructional tasks.

What is of interest in regard to the paperback book, non-book materials, and microforms is not the proportion of institutions which are using them, but the number which are not. For example, 9 per cent (71) reported that they did not use paperbound books. The most recent issue of Paperbound Books in Print lists 48,200 titles. $^{7}$ Libraries which reported that they did not use paperbound books apparently also reject those titles which appear in that form only. The use of miniaturized print materials on film will probably become universal as soon as the reading machines are improved. Haverford College is now acquiring more than three thousand pages of microprint on 6 by 9 inch microcards representing the writings of more than three hundred outstanding scientists, all in their original languages. It is reported that officials of the Readex Microprint Corporation claim that it would cost about $\$ 20$ million to form a collection of the editions which are to be reproduced. ${ }^{8}$

Responses dealing with physical facilities, carrels and listening facilities, as well as dial access systems reflect a focus on the individual and individualized study facilities. An exciting development in regard to individual seating spaces in the library are the 172 (22 per cent) institutions-the largest number planning any innovation-reporting that they are planning to introduce electronically equipped carrels. This development has implications for change in pedagogical method as well as for the redeployment of teaching staff and suggests a closer linkage between the classroom and the library. Many of the librarians reported that they are waiting only for new buildings before they introduce "hot" carrels as well

\footnotetext{
7 Paperbound Books in Print, XIII, No. 2 (New York: Bowker, February 1968). 18.

${ }^{8}$ Educational Technology, VII (March 15, 1967),
}

as other innovations. Sophisticated systems of this character have been established at Oklahoma Christian College (Oklahoma City) and Oral Roberts University (Tulsa), and are scheduled for installation in the Texas Junior College library in Tyler, Texas. At the lastnamed institution prerecorded television and audiotape lessons are being installed at two hundred individual study locations (forty equipped for television). These carrels, designed to serve three thousand students, will be available fifteen hours a day. At Oklahoma Christian College the major innovative use of the carrel is in listening to a tape made by a course instructor and keyed for use with a workbook. This procedure evolved from an experiment with classes in public speaking begun in 1963 by R. Stafford North, the dean of instruction. He reported that (1) students learned as effectively through the tape-workbook method as by the traditional lecture method, (2) the materials were relatively inexpensive to produce, (3) most students preferred the tape-workbook method, and (4) its use effected a saving in faculty time. The new three-story learning center at Oklahoma Christian College can accommodate 1,008 study carrels each equipped with a telephone dial and headset connected to the control center.

Librarians were not as responsive to the list of special library services as they were to the other categories. Special libraries usually function in a commercial or industrial setting. Its proponents claim that special library services are more closely supportive of the purposes of the parent institution than the academic library is of the college. College libraries have long been producing accessions lists and selective bibliographies, at least for faculty use; some have abandoned these services because of their cost. Other special library services have had little impact on the academic library. A number of the responding librarians noted that such services would require increased 
professional staffs with greater subject specialization and larger resources. Those institutions which report existing table of contents services (41-6 per cent) and selective dissemination of information (91-12 per cent) may be reflecting a capability made possible by the widespread distribution of photocopy equipment. A few librarians noted that they did not understand the meaning of the checklist references to special library services.

Some of the responses were not as precise or meaningful as they might have been had the checklist items been phrased differently. Nomenclature, such as the reference to mechanized circulation which is subject to more than one interpretation, represents one kind of problem. The fact that the list is incomplete probably resulted in failure to elicit precise figures as to institutions using the range of technical equipment for operations in acquisitions, cataloging, serials control, binding, or book catalog production, or those institutions entering on cooperative programs.

If any generalization can be drawn from the data, it is that the library is in a state of flux. The increasing momentum of change is particularly apparent if one examines some of the literature bearing on the college library associated with a liberal arts program. Guy R. Lyle, authority on the American college library, recorded the changes that have taken place in the first part of this century. He concluded: "Not until the twentieth century, and for many colleges not until the twenties and thirties of this century, was there any pronounced change in the traditional role of the library as a storehouse of books and the librarian as guardian of these books."?

There have been a number of recorded observations which cast further light on the library, from which both the student and professor draw their sustenance. As recently as 1955, Wyman W.

- Guy R. Lyle, The Administration of the College Library, 3d ed. (New York: H. W. Wilson, 1961), p. 1.
Parker described the liberal arts college library entirely in terms of its traditional book stock. ${ }^{10}$ Joseph N. Whitten in a 1958 New York University doctoral dissertation focused on instructional service as an essential component of the liberal arts college library. He said that librarians had not fully realized the extent to which they may become engaged in instructional procedures. He concluded that they ought to do so, and that their doing so could be "a major and necessary support to the teaching process."11 Weh Chao Chen, professor of political science and librarian at Kalamazoo College (Michigan) urged in 1960 that the college library abandon its storehouse role and: (1) relate its collections more closely to the academic program; (2) teach students learning skills; (3) reduce student demand for faculty time; and (4) assist faculty members in their research activities. Presumably steps taken to accomplish these goals would be innovational. ${ }^{12}$ Further, Benjamin F. Smith in a 1964 article in Improvement of College and University Teaching said that the college library was handicapped in fulfilling its educational mission by the burden of a system of reserve books which, in his opinion, represented an extension of the textbook. He looked to a resolution of the reserve book problem for improvement of the library. ${ }^{13}$ The problem remains to be resolved.

Most recent developments appear to be determined by the library's reflection of the impact of both technology and independent study programs accompanied by the demand for a wider range of instructional support services. The co-

${ }^{10} \mathrm{~W}$. W. Parker, "Library in the Liberal Arts College," CRL, XVI (April 1955), 177-82.

${ }^{11}$ Joseph N. Whitten, Relationship of College Instruction to Libraries in 72 Liberal Arts Colleges ${ }_{r}$ Abstract $_{1}$ (New York: 1958). Dissertation Abstracts, XIX (January 1959), 1766.

12 Wen Chao Chen, "A Sound Library Service for the Small College," Liberal Education, XLVI (Mav 1960 ), 233-40.

${ }^{13}$ Benjamin F. Smith, "Book Reserve System," Improving College and University Teaching, XII (Spring 1964), 83ff. 
herence of these factors is evidenced in the new learning centers and learning resource centers, and in the LibraryCollege movement.

Learning resource centers exemplify the thesis that films, slides, tapes, and television can and must be used for instructional purposes. These centers are also bringing to the campus "stored knowledge" in all forms, printed, photographic, and electronic. The conceptualization and administrative structure of the learning center varies; some are integrated with the library, others are managed separately in the same building with the book and periodical collections or in close proximity to them. ${ }^{14}$ Learning resource centers have been growing vigorously in the secondary schools since the American Association of School Librarians has encouraged the school librarian to assume responsibility for such comprehensive materials centers; their development at the college level appears to be much slower. Central Washington State College includes within its instructional materials center, in addition to the general book and periodical collection, a curriculum materials library, a music listening area, a film library, a closed-circuit television department, a tape drill laboratory, and an instructional materials production department. ${ }^{15}$

The "Library-College" has been variously described. It is concerned with changing the mode of instruction from the classroom lecture arrangement with the library as a supporting agency, to the electronic carrel in the library with the teaching/learning process dependent upon the individual and independent efforts of the student. One of its purposes is to develop a more vital relationship between the librarian and college teach-

\footnotetext{
14 California State College, Hayward, Learning Resources for Colleges and Universities. Produced by Fred Harcleroad, Principal Investigator of Project No. OE-3-16-025, Educational Media Branch, Office of Education, U.S. Dept. of Health, Education and Welfare, September 1964.

${ }^{15}$ William D. Schmidt, "IMS Production Facilities: Central Washington State College," Audiovisual Instruction, XII (October 1967), 805-7.
}

ing. ${ }^{16}$ Recent impetus to this "movement" is derived from the Library-College Newsletter which began publication in May 1965, and in the supporting conferences sponsored by the graduate school of library science of the Drexel Institute of Technology. Jamestown College (North Dakota) defined the Library-College in its charter: "The purpose of the Library-College is to increase the effectiveness of student learning particularly through the use of library-centered independent study with a bibliographically expert faculty." 17 Louis Shores, an enthusiastic proponent of the Library-College movement, claims that one hundred institutions now have libraries "in which the carrel has replaced the classroom as the center of learning."18 Antioch, Stephens, Elmira, and Florida Presbyterian are among the institutions in the vanguard of this development.

It appears that the library is moving from a passive role and becoming an active instrument in the process of teaching and learning. The librarian is responding to the inadequacy of traditional techniques of administration and record keeping. Perhaps the major constant on the library scene is change itself. Yet one senses that library patrons are establishing new requirements and are bringing to the college library new levels of expectation. Programs of universal education-the development of each individual to the maximum of his capabilities-require that the librarian provide all the information that any individual may need, from any part of the world, and at the time and place that he needs it. To accomplish these goals more dramatic changes may be expected in the library of the future than have been evident in the past.

\footnotetext{
${ }^{16}$ Patricia B. Knapp, The Monteith College Library Experiment (New York: the Scarecrow Press, Inc., 1966).

${ }^{17}$ Louis Shores, Robert Jordan, and John Harvey, The Library-College (Philadelphia: Drexel Press, 1966), p. ix.

${ }^{18}$ Louis Shores, “The Medium Way," Library-College Journal, I (Winter 1968), 16.
} 


\section{APPENDIX}

There follows a list of innovational practices. in the near future. For the purpose of this

In Column A indicate by check $(\sqrt{ })$ whether in your estimation you are doing anything innovative or unusual in this area, or if you are planning to do anything innovative or unusual study innovation is defined as a new practice or procedure for your institution.

In Column B indicate by check $(\checkmark)$ the time of the introduction of the innovative practice.

\begin{tabular}{|c|c|c|c|c|c|}
\hline & \multicolumn{3}{|c|}{ Column A } & \multicolumn{2}{|c|}{ Column B } \\
\hline & Yes & No & $\begin{array}{l}\text { Introduced } \\
\text { Prior to } \\
1961\end{array}$ & $\begin{array}{l}\text { Introduced } \\
\text { in } 1961 \\
\text { or after }\end{array}$ & $\begin{array}{c}\text { Planning } \\
\text { to } \\
\text { Introduce }\end{array}$ \\
\hline \multicolumn{6}{|l|}{ Administrative Practices: } \\
\hline $\begin{array}{c}\text { Change to LC Classification } \\
\text { System }\end{array}$ & $\begin{array}{l}336 \\
43 \%\end{array}$ & $\begin{array}{l}361 \\
46 \%\end{array}$ & $\begin{array}{l}90 \\
12 \%\end{array}$ & $\begin{array}{l}243 \\
31 \%\end{array}$ & $\begin{array}{l}79 \\
10 \%\end{array}$ \\
\hline Dormitory-Type Libraries & $\begin{array}{l}75 \\
10 \%\end{array}$ & $\begin{array}{l}576 \\
74 \%\end{array}$ & $\begin{array}{l}32 \\
4 \%\end{array}$ & $\begin{array}{l}34 \\
4 \%\end{array}$ & 22 \\
\hline $\begin{array}{l}\text { Multi-Media Materials in } \\
\text { General Catalog }\end{array}$ & $\begin{array}{l}363 \\
46 \%\end{array}$ & $\begin{array}{l}311 \\
40 \%\end{array}$ & $\begin{array}{l}156 \\
20 \%\end{array}$ & $\begin{array}{l}152 \\
20 \%\end{array}$ & $\begin{array}{l}77 \\
10 \%\end{array}$ \\
\hline $\begin{array}{c}\text { Special Catalog of Multi- } \\
\text { Media Materials }\end{array}$ & $\begin{array}{l}231 \\
30 \%\end{array}$ & $\begin{array}{l}406 \\
52 \%\end{array}$ & $\begin{array}{l}96 \\
12 \%\end{array}$ & $\begin{array}{l}97 \\
12 \%\end{array}$ & $\stackrel{41}{5 \%}$ \\
\hline $\begin{array}{l}\text { Participate in Storage Depos- } \\
\text { itory Program }\end{array}$ & $\begin{array}{l}81 \\
10 \%\end{array}$ & $\begin{array}{l}573 \\
74 \%\end{array}$ & 29 & 22 & 52 \\
\hline Library-College & $\begin{array}{l}84 \\
10 \%\end{array}$ & $\begin{array}{l}415 \\
53 \%\end{array}$ & 27 & $11 \%$ & 37 \\
\hline $\begin{array}{l}\text { Multi-Media Instruction in Li- } \\
\text { brary Use }\end{array}$ & $\begin{array}{l}240 \\
31 \%\end{array}$ & $\begin{array}{l}402 \\
51 \%\end{array}$ & $\stackrel{56}{7 \%}$ & $\begin{array}{l}114 \\
15 \%\end{array}$ & $\begin{array}{l}93 \\
12 \%\end{array}$ \\
\hline $\begin{array}{c}\text { Commercial Cataloging/Proc- } \\
\text { essing }\end{array}$ & $\begin{array}{l}71 \\
9 \%\end{array}$ & 590 & $\stackrel{18}{2 \%}$ & 38 & $\stackrel{29}{4 \%}$ \\
\hline $\begin{array}{c}\text { Cooperative Cataloging/Proc- } \\
\text { essing }\end{array}$ & $\begin{array}{l}77 \\
10 \%\end{array}$ & $\begin{array}{l}556 \\
71 \%\end{array}$ & 15 & $23 \%$ & $\begin{array}{l}67 \\
9 \%\end{array}$ \\
\hline $\begin{array}{l}\text { Automation: } \\
\text { Teletypewriter }\end{array}$ & $\begin{array}{l}91 \\
12 \%\end{array}$ & $\begin{array}{l}551 \\
71 \%\end{array}$ & $\begin{array}{l}9 \\
1 \%\end{array}$ & 60 & 87 \\
\hline $\begin{array}{l}\text { Mechanized Circulation Sys- } \\
\text { tem }\end{array}$ & $\begin{array}{l}155 \\
17 \%\end{array}$ & $\begin{array}{l}498 \\
64 \%\end{array}$ & $\begin{array}{l}15 \\
2 \%\end{array}$ & $\begin{array}{l}85 \\
11 \%\end{array}$ & $\begin{array}{l}125 \\
16 \%\end{array}$ \\
\hline Facsimile Transmission & $\begin{array}{l}36 \\
5 \%\end{array}$ & $\begin{array}{l}589 \\
75 \%\end{array}$ & 1 & $\begin{array}{l}18 \\
2 \%\end{array}$ & $\begin{array}{l}43 \\
6 \%\end{array}$ \\
\hline Reader Printer & $\begin{array}{l}408 \\
52 \%\end{array}$ & $\begin{array}{l}260 \\
33 \%\end{array}$ & $\begin{array}{l}54 \\
7 \%\end{array}$ & $\begin{array}{l}276 \\
36 \%\end{array}$ & 134 \\
\hline Photocopying . & $\begin{array}{l}630 \\
81 \%\end{array}$ & $\begin{array}{l}74 \\
9 \%\end{array}$ & $\begin{array}{l}102 \\
13 \%\end{array}$ & $\begin{array}{l}476 \\
61 \%\end{array}$ & 32 \\
\hline Edge Notched Cards & $\begin{array}{c}101 \\
13 \%\end{array}$ & $\begin{array}{c}548 \\
70 \%\end{array}$ & $\stackrel{42}{5 \%}$ & $\begin{array}{l}49 \\
6 \%\end{array}$ & 10 \\
\hline Dial-Access & $\begin{array}{c}50 \\
6 \%\end{array}$ & $\begin{array}{l}583 \\
75 \%\end{array}$ & 0 & $\begin{array}{l}10 \\
1 \%\end{array}$ & $\begin{array}{l}58 \\
7 \%\end{array}$ \\
\hline
\end{tabular}




\begin{tabular}{|c|c|c|c|c|c|}
\hline & \multicolumn{3}{|c|}{ Column A } & \multicolumn{2}{|c|}{ Column B } \\
\hline & Yes & No & $\begin{array}{l}\text { Introduced } \\
\text { Prior to } \\
1961\end{array}$ & $\begin{array}{l}\text { Introduced } \\
\text { in } 1961 \\
\text { or after }\end{array}$ & $\begin{array}{l}\text { Planning } \\
\text { to } \\
\text { Introduce }\end{array}$ \\
\hline Computer Use: & 99 & & 1 & & \\
\hline Acquisition . . . . . & $13 \%$ & $66 \%$ & 1 & $4 \%$ & $14 \%$ \\
\hline Purchasing . . . . . & $\begin{array}{l}83 \\
11 \%\end{array}$ & $\begin{array}{l}575 \\
74 \%\end{array}$ & 3 & 24 & $\begin{array}{l}92 \\
12 \%\end{array}$ \\
\hline Inventory Control (Shelf List) & 60 & $\begin{array}{l}552 \\
71 \%\end{array}$ & 0 & $\stackrel{15}{2 \%}$ & $\begin{array}{l}86 \\
11 \%\end{array}$ \\
\hline Circulation & $\begin{array}{l}88 \\
11 \%\end{array}$ & $\begin{array}{l}536 \\
69 \%\end{array}$ & 1 & $\stackrel{36}{5 \%}$ & $\begin{array}{l}105 \\
13 \%\end{array}$ \\
\hline $\begin{array}{c}\text { KWIC (Key-Word-In-Con- } \\
\text { text) Indexing }\end{array}$ & $\stackrel{16}{2 \%}$ & $\begin{array}{l}598 \\
77 \%\end{array}$ & 0 & $11 \%$ & $13 \%$ \\
\hline $\begin{array}{l}\text { KWOC (Key-Word-Out-Of- } \\
\text { Context) Indexing }\end{array}$ & $\begin{array}{l}5 \\
1 \%\end{array}$ & 601 & 0 & 1 & $\begin{array}{l}5 \\
1 \%\end{array}$ \\
\hline Materials: & & & & & \\
\hline Paperbacks & $\begin{array}{l}622 \\
80 \%\end{array}$ & $\stackrel{71}{9 \%}$ & $\begin{array}{l}424 \\
54 \%\end{array}$ & $\begin{array}{l}151 \\
19 \%\end{array}$ & 1 \\
\hline $\begin{array}{c}\text { Non-Book } \\
\text { Tapes) }\end{array}$ & $\begin{array}{l}571 \\
73 \%\end{array}$ & 117 & $\begin{array}{l}354 \\
45 \%\end{array}$ & $\begin{array}{l}176 \\
23 \%\end{array}$ & $\begin{array}{l}48 \\
6 \%\end{array}$ \\
\hline Microforms & $\begin{array}{l}646 \\
83 \%\end{array}$ & $\begin{array}{l}65 \\
8 \%\end{array}$ & $\begin{array}{l}218 \\
28 \%\end{array}$ & $\begin{array}{l}214 \\
28 \%\end{array}$ & 21 \\
\hline Physical Facilities: & & & & & \\
\hline Carrels . . . . . . . . & $\begin{array}{l}617 \\
79 \%\end{array}$ & $\begin{array}{l}91 \\
12 \%\end{array}$ & $\begin{array}{l}293 \\
38 \%\end{array}$ & $\begin{array}{l}276 \\
35 \%\end{array}$ & $\begin{array}{l}110 \\
14 \%\end{array}$ \\
\hline $\begin{array}{l}\text { Electronically Equipped Car- } \\
\text { rels }\end{array}$ & $\begin{array}{l}113 \\
14 \%\end{array}$ & 517 & $\begin{array}{l}8 \\
1 \%\end{array}$ & 38 & $\begin{array}{l}172 \\
22 \%\end{array}$ \\
\hline Listening Facilities & 511 & $\begin{array}{l}160 \\
20 \%\end{array}$ & $\begin{array}{l}228 \\
29 \%\end{array}$ & $\begin{array}{l}230 \\
29 \%\end{array}$ & $\begin{array}{l}131 \\
17 \%\end{array}$ \\
\hline $\begin{array}{l}\text { Special Library Services and } \\
\text { Techniques: }\end{array}$ & & & & & \\
\hline Table of Contents Service & $\stackrel{67}{9 \%}$ & $\begin{array}{l}540 \\
69 \%\end{array}$ & $\begin{array}{l}8 \\
1 \%\end{array}$ & $\stackrel{41}{5 \%}$ & 30 \\
\hline $\begin{array}{l}\text { Selective Dissemination of } \\
\text { Information }\end{array}$ & 113 & $\begin{array}{l}484 \\
62 \%\end{array}$ & $\begin{array}{l}54 \\
7 \%\end{array}$ & 37 & 24 \\
\hline Selective Bibliography & $\begin{array}{l}279 \\
36 \%\end{array}$ & $\begin{array}{l}342 \\
44 \%\end{array}$ & $\begin{array}{l}148 \\
19 \%\end{array}$ & $\begin{array}{l}79 \\
10 \%\end{array}$ & $\begin{array}{l}45 \\
6 \%\end{array}$ \\
\hline Accession List Publication & $\begin{array}{l}492 \\
63 \%\end{array}$ & $\begin{array}{l}190 \\
24 \%\end{array}$ & $\begin{array}{l}334 \\
43 \%\end{array}$ & $\begin{array}{l}129 \\
29 \%\end{array}$ & 23 \\
\hline $\begin{array}{l}\text { Technical Report Coverage } \\
\text { (e.g. ERIC) }\end{array}$ & $\begin{array}{l}126 \\
16 \%\end{array}$ & $\begin{array}{l}474 \\
61 \%\end{array}$ & $\begin{array}{c}15 \\
2 \%\end{array}$ & $\begin{array}{l}79 \\
10 \%\end{array}$ & $\begin{array}{l}28 \\
4 \%\end{array}$ \\
\hline
\end{tabular}

